Jurnal Hukum Mimbar Justitia

Fakultas Hukum Universitas Suryakancana

Vol. 6 No. 2 - Desember 2020, hlm. 129-152.

ISSN: 2477-5681 (Cetak), ISSN: 2580-0906 (Online)

Open Access at: https://jurnal.unsur.ac.id/jmi

\title{
PERLINDUNGAN HUKUM BAGI PEMBERI PINJAMAN ATAS RISIKO KREDIT \\ DALAM PELAKSANAAN PINJAM MEMINJAM UANG BERBASIS \\ TEKNOLOGI INFORMASI (PEER TO PEER LENDING)
}

\author{
Indah Kusuma Wardhani \\ Universitas Borobudur \\ Email: indah_kusuma_wardhani@yahoo.com \\ dan \\ Fawzia Apriandini \\ Universitas Borobudur \\ Email: fawziaprian@gmail.com
}

Masuk: September 2020 Penerimaan: Oktober 2020 Publikasi: Desember 2020

\begin{abstract}
ABSTRAK
Financial Technology (fintech) yang paling cepat berkembang di Indonesia adalah fintech jenis peer to peer lending, dimana nasabah dapat memperoleh pinjaman dengan cara yang sederhana, mudah, cepat, dan tanpa harus memiliki jaminan. Namun dalam pelaksanaannya, fintech ini memiliki risiko kredit yang sangat tinggi karena kemampuan perusahaan fintech sebagai penyelenggara dalam melakukan penilaian terhadap calon penerima pinjaman tidak sebaik lembaga keuangan lainnya. Oleh karena itu, diperlukan adanya perlindungan hukum yang bersifat preventif dan represif, terutama bagi pihak pemberi pinjaman, yang diatur dalam Peraturan OJK No. 77/POJK.01/2016 tentang Pelaksanaan Pinjam Meminjam Uang Berbasis Teknologi Informasi dan Peraturan OJK No. 1/POJK.07/2013 tentang Perlindungan Konsumen Sektor Jasa Keuangan. Dengan adanya kedua Peraturan OJK tersebut, pihak pemberi pinjaman telah mendapat perlindungan hukum yang cukup, namun perlindungan hukum tersebut harus lebih ditingkatkan, terutama dalam hal mitigasi risiko kredit.
\end{abstract}

Kata Kunci : Perlindungan Hukum Bagi Pemberi Pinjaman, Peer to Peer Lending, Risiko Kredit.

\section{ABSTRACT}

The fastest growing financial technology (fintech) in Indonesia is peer to peer lending, where customers could obtain loans in a simple, easy, and fast way, yet without collateral. However, in practice, peer to peer lending has a very high credit risk because the ability of fintech companies in assessing prospective loan recipients is not as good as other financial institutions. Therefore, preventive and repressive legal protection are 
needed, especially for lenders, which are regulated in OJK Regulation Number 77/POJK.01/2016 concerning the Implementation of Information Technology-Based Lending and Borrowing and OJK Regulation Number 1/POJK.07/2013 concerning Consumers' Protection in Financial Services Sector. With the two OJK Regulations, lenders have received sufficient legal protection, but it must be further strengthened, especially in terms of credit risk mitigation.

Keywords : Legal Protection for Lenders, Peer To Peer Lending, Credit Risk.

\section{PENDAHULUAN}

Kemunculan teknologi informasi dan internet yang terus mengalami pertumbuhan pesat di Indonesia menyebabkan adanya keterpaduan antara perkembangan teknologi informasi dengan media dan telekomunikasi, pada saat ini telah mengakibatkan semakin beragamnya jasa dan produk yang ada. Perkembangan teknologi informasi ini terlihat dari munculnya berbagai jenis kegiatan yang berbasis pada teknologi, seperti e-commerce dan e-goverment. ${ }^{1}$

Sistem informasi dan komunikasi elektronik saat ini telah diimplementasikan pada sebagian besar sektor kehidupan masyarakat, sehingga mengakibatkan terciptanya suatu pasar baru yang telah mendorong

1 Nurudin, 2012, Media Sosial Baru dan Munculnya Revolusi Proses Komunikasi, Buku Litera, Yogyakarta, hlm. 51. perkembangan sistem ekonomi masyarakat, dari ekonomi tradisional yang berbasis teknologi manufaktur ke arah ekonomi digital yang berbasiskan informasi, kreativitas intelektual dan ilmu pengetahuan atau dikenal dengan istilah ekonomi kreatif.

Perkembangan sistem ekonomi ini juga berpengaruh pada perkembangan hukum ekonomi yang memiliki tujuan untuk mengatur dan membatasi setiap kegiatan ekonomi yang ada dalam masyarakat dengan harapan pembangunan perekonomian tidak mengabaikan hak-hak dan kepentingan masyarakat yang dilindungi oleh negara. ${ }^{2}$

Bentuk dari adanya kreativitas ekonomi juga mempengaruhi sistem keuangan di suatu negara, dimana

2 Elsi Kartika Sari dan Advendi Simangunsong, 2007, Hukum Dalam Ekonomi, PT Gramedia Widiasarana, Jakarta, hlm. 4. 
Indah Kusuma Wardhani dan Fawzia Apriandini

Jurnal Hukum Mimbar Justitia

Vol. 6 No. 2 - Desember 2020

sistem keuangan tersebut memainkan peranan penting dalam meningkatkan pertumbuhan dan kesehatan perekonomian suatu negara secara berkelanjutan dan seimbang. ${ }^{3}$ Sistem keuangan berfungsi sebagai fasilitator perdagangan domestik dan internasional, memobilisasi simpanan menjadi berbagai instrumen investasi dan menjadi perantara antara penabung dan investor. ${ }^{4}$

Bank menjadi lembaga keuangan yang berperan penting dalam sistem pengelolaan keuangan negara khususnya dalam usaha negara untuk melakukan pemerataan ekonomi bagi seluruh rakyat Indonesia. Tetapi pada dasarnya apa yang dicita-citakan oleh negara dalam pemerataan ekonomi terhambat oleh keadaan struktur geografis Indonesia yang bersifat kepulauan. Sulitnya akses hingga ke pelosok-pelosok daerah menyebabkan masih jarangnya lembaga keuangan yang mendirikan usaha di sana. Dalam hal ini, Deputi Keuangan OJK

3 Gazali S. Djoni dan Rachmadi Usman, 2010, Hukum Perbankan, Sinar Grafika, Jakarta, hlm. 39.

4 Ibid., hlm. 41. menjelaskan bahwa jumlah penduduk dewasa yang memiliki akun rekening di perbankan hanya sekitar $60 \%$ dari total keseluruhan penduduk Indonesia pada April 2019 padahal target yang seharusnya didapatkan adalah sebesar $75 \% .^{5}$

Oleh sebab itu munculnya teknologi informasi turut pula dimanfaatkan oleh lembaga-lembaga keuangan untuk berinovasi menyelaraskan kegiatan-kegiatan lembaga keuangan dengan memanfatkan teknologi informasi dan internet atau lebih dikenal dengan istilah fintech. Fintech merupakan variasi model bisnis dan perkembangan teknologi yang memiliki potensi untuk meningkatkan industri layanan keuangan. ${ }^{6}$ Fintech biasanya didirikan oleh perusahaan perintis yaitu suatu badan hukum atau perseorangan yang memulai mengerjakan sesuatu atau

5 https://finance.detik.com/moneter/d4522143/ojk-sebut-cuma-60-orang-ripunya-rekening-bank, diakses tanggal 10 Agustus 2020, pukul 14.30 WIB.

6 Otoritas Jasa Keuangan, 2017, Kajian Perlindungan Konsumen Sektor Jasa Keuangan: Perlindungan Konsumen Pada Fintech, Departemen Perlindungan Konsumen OJK, Jakarta, hlm. 8. 
Indah Kusuma Wardhani dan Fawzia Apriandini

Jurnal Hukum Mimbar Justitia

Vol. 6 No. 2 - Desember 2020

baru pertama atau permulaan ${ }^{7}$ atau disebut start up company yang melakukan kegiatan keuangan dengan cara memadukan kegiatan finansial dan teknologi informasi serta internet. Kemudahan yang ditawarkan oleh fintech mulai dari efisiensi waktu, efisiensi biaya, dan kecepatan, serta keamanan proses dan sistem keuangan menjadi salah satu penyebab dari meningkatnya pengguna fintech.

Perkembangan fintech yang cukup pesat menjadikan fintech terus berinovasi mengikuti arah perkembangan dan untuk memenuhi kebutuhan manusia yang serba instan. Inovasi pada fintech ini berdasarkan atas banyaknya jenis fintech yang berkembang di dunia, seperti peer to peer lending ( $P 2 P$ lending); manajemen risiko investasi; payment, clearing, and settlement; serta market aggregator. ${ }^{8}$ Akan tetapi sejak awal kemunculannya

7 https://kbbi.kemdikbud.go.id/entri/perintis, diakses tanggal 10 Agustus 2020 pukul 15.00 WIB.

8 Dita Tania Pratiwi, 2020, "Perlindungan Hukum Terhadap Konsumen (Penerima Pinajaman) Financial Technology yang Berbasis Peer to Peer Lending di Indonesia", Jurnal Hukum Adiguna, Vol. 3 No. 1, Fakultas Hukum Universitas Tarumanegara, Jakarta, hlm. 474-475. pada tahun 2016 hingga tahun 2019 jenis fintech yang paling banyak digunakan oleh masyarakat Indonesia adalah fintech jenis peer to peer lending yang dibuktikan dengan adanya 113 perusahaan fintech tersebut yang terdaftar di OJK sepanjang 31 Mei 2019. ${ }^{9}$

OJK sebagai lembaga yang berfungsi menyelenggarakan sistem pengaturan dan pengawasan terhadap seluruh kegiatan di dalam sektor jasa keuangan, berarti OJK memiliki tugas untuk mengatur pelaksanaan pinjam meminjam uang berbasis teknologi informasi (peer to peer lending) di Indonesia. Oleh sebab itu OJK mengeluarkan POJK No. 77/POJK.01/2016 tentang Layanan Pinjam Meminjam Uang Berbasis Teknologi Informasi, yang didalamnya dijelaskan pengertian layanan pinjam meminjam uang berbasis teknologi informasi yaitu:

\footnotetext{
9 https://www.ojk.go.id/id/berita-dankegiatan/publikasi/Pages/PenyelenggaraFintech-Terdaftar-dan-Berizin-di-OJK-per31-Mei-2019, diakses tanggal 12 Agustus 2020 pukul 17.40 WIB.
} 
“Penyelenggaraan layanan jasa keuangan untuk mempertemukan pemberi pinjaman dengan penerima pinjaman dalam rangka melakukan perjanjian pinjam meminjam dalam mata uang rupiah secara langsung melalui sistem elektronik dengan menggunakan jaringan internet." 10

Dengan dikeluarkannya POJK No. 77/POJK.01/2016 tersebut, diharapkan dalam pelaksanaan peer to peer lending di Indonesia dapat berjalan sesuai dengan aturan hukum dan tidak ada pihak-pihak yang dirugikan. Akan tetapi pada kenyataannya, pelaksanaan peer to peer lending ini mengalami berbagai permasalahan, baik yang berkaitan dengan tindak pidana maupun yang berkaitan dengan nasib pemberi pinjaman. Sebagai pihak yang meminjamkan dananya kepada penerima pinjaman berdasarkan atas penilaian yang dilakukan oleh pihak penyelenggara, ada kemungkinan terjadinya gagal bayar (kredit macet). Dalam hal ini, pihak penyelenggara tidak dapat diminta

10 POJK No. 77/POJK.01/2016 tentang Layanan Pinjam Meminjam Uang Berbasis Teknologi Informasi, Pasal 1 angka 3. pertanggungjawabannya karena risiko gagal bayar (kredit macet) sepenuhnya menjadi beban pemberi pinjaman, sebagaimana yang dicantumkan di dalam aplikasi dan situs website dari masing-masing penyelenggara.

Pada bulan April 2019 OJK mengeluarkan pernyataan bahwa rasio kredit macet (NPL/Non Performing Loan) pada perusahaan fintech mengalami peningkatan dan sudah mencapai 3,18\% sedangkan rasio kredit kurang lancar mencapai 3,17\%, dimana jika diparalelkan dengan bank yang jumlahnya mencapai $6,35 \%$, berarti bahwa risiko kredit pada perusahaan fintech sangat tinggi jika dibandingkan dengan risiko kredit pada bank. ${ }^{11} \mathrm{Hal}$ ini disebabkan oleh kemampuan perusahaan fintech dalam melakukan penilaian terhadap calon penerima pinjaman tidak sebaik bank, karena dalam pemberian kredit bank harus melakukan penilaian yang seksama terhadap watak, kemampuan, modal,

11

https://www.cnbcindonesia.com/finte ch/20190401112121-37-64008/kreditmacet-fintech-tembus-318-perlukahkhawatir, diakses tanggal 12 Agustus 2020 pukul 08.20 WIB. 
Indah Kusuma Wardhani dan Fawzia Apriandini

Jurnal Hukum Mimbar Justitia

Vol. 6 No. 2 - Desember 2020

agunan, dan prospek usaha dari calon debitur.

Dalam peer to peer lending, pemberian pinjaman dana didasarkan pada hasil penilaian yang telah dilakukan oleh pihak penyelenggara dan biasanya pemberi pinjaman langsung menyetujuinya. Dengan demikian, pihak penyelenggara mempunyai andil yang cukup besar dalam menentukan kepada siapakah dana tersebut diberikan. Prinsip kehatihatian yang diterapkan oleh bank dalam pemberian kredit juga harus diterapkan oleh perusahaan fintech agar dapat menekan terjadinya risiko kredit macet.

Berdasarkan uraian tersebut, penulis akan membahas permasalahan mengenai pelaksanaan peer to peer lending di Indonesia dan bentuk perlindungan hukum bagi pemberi pinjaman atas risiko kredit dalam pelaksanaan peer to peer lending.

\section{METODE PENELITIAN}

Dalam penelitian ini digunakan metode yuridis normatif, yaitu penelitian yang menggunakan data sekunder yang diperoleh melalui studi kepustakaan dengan cara menelaah literatur, artikel, liputan, makalah, serta peraturan perundang-undangan berkaitan objek penelitian. ${ }^{12}$ Data sekunder terdiri dari bahan hukum primer, bahan hukum sekunder, dan bahan hukum tersier. Selanjutnya data sekunder tersebut dinalisis secara kualitatif dan disajikan dalam bentuk deskriptif.

\section{PEMBAHASAN}

A. Pelaksanaan Pinjam Meminjam Uang Berbasis Teknologi
Informasi (Peer to Peer Lending) di Indonesia.

Perkembangan fintech yang sangat pesat menjadikannya terus berinovasi ke berbagai sistem keuangan, salah satu yang paling diminati di Indonesia adalah fintech dengan jenis peer to peer lending, yaitu suatu platform yang dijadikan sebagai wadah/tempat saling bertemunya pemberi pinjaman dan penerima

12 Soerjono Soekanto, 2012, Pengantar Penelitian Hukum, UI Press, Jakarta, hlm. 52. 
Indah Kusuma Wardhani dan Fawzia Apriandini

Jurnal Hukum Mimbar Justitia

Vol. 6 No. 2 - Desember 2020

pinjaman untuk melakukan pinjam meminjam uang secara elektronik.

Target pemasaran peer to peer lending pada umumnya dibedakan menjadi dua. Pertama, pelaku Usaha Mikro, Kecil dan Menengah (UMKM) yang ingin membuat atau mengembangkan usahanya tetapi tidak memiliki modal yang cukup sehingga diperlukan adanya suntikan dana dari pihak lain, seperti Suasana Kopi dan Button Scarves. ${ }^{13}$ Kedua, perorangan yang membutuhkan pinjaman untuk memenuhi kebutuhan sehari-hari atau dikenal dengan istilah kredit konsumtif. Perbedaan kedua target pemasaran tersebut adalah pinjaman yang diperuntukkan bagi UMKM merupakan kredit produktif dan biasanya jumlah pinjamannya cukup besar sehingga diperlukan adanya agunan berupa aset milik UMKM tersebut. Sedangkan pinjaman yang diperuntukkan bagi perorangan merupakan kredit konsumtif dan rata-rata peminjam

13

https://www.cnbcindonesia.com/tech/2019 1014113024-37-106736/berkat-fintechlending-sederet-umkm-ini-bisa-naik-kelas, diakses tanggal 12 Agustus 2020 pukul 20.02 WIB. berasal dari kalangan kelas menengah ke bawah yang biasanya mereka adalah orang-orang yang tidak memiliki pekerjaan atau penghasilan tetap, sehingga pinjaman ini memiliki risiko kredit atau kemungkinan terjadinya gagal bayar yang semakin besar pula.

Dalam pelaksanaan peer to peer lending, pemilik platform (aplikasi) atau disebut pihak penyelenggara mempunyai andil yang cukup besar karena ia memiliki wewenang untuk menentukan kepada siapakah dana dari pemberi pinjaman akan dipinjamkan. Selain itu dalam praktiknya pemberi pinjaman hanya sebagai pihak yang menginvestasikan dananya kepada penyelenggara untuk dikelola dan disalurkan dalam bentuk pinjaman kepada penerima pinjaman melalui website yang dimiliki oleh penyelenggara. Jadi penyelenggara hanya menyediakan fasilitas berupa website yang mempertemukan pemberi pinjaman dan penerima pinjaman dengan berdasarkan pada kuasa yang telah diberikan oleh pemberi pinjaman kepada penyelenggara. Dalam hal ini, 
Indah Kusuma Wardhani dan Fawzia Apriandini

Jurnal Hukum Mimbar Justitia

Vol. 6 No. 2 - Desember 2020

penyelenggara untuk dan atas nama pemberi pinjaman menyepakati perjanjian pinjam meminjam uang dengan penerima pinjaman. Oleh karena itu, diperlukan adanya escrow account dan virtual account yang diterbitkan oleh bank. Berdasarkan hal tersebut, konstruksi hubungan hukum antara pemberi pinjaman dan penyelenggara adalah hubungan hukum yang lahir dari perjanjian pemberian kuasa sebagaimana diatur dalam Buku III Bab XVI Pasal 1792 s.d Pasal 1819 KUHPerdata, dimana pemberi pinjaman sebagai pemberi kuasa dan penyelenggara sebagai penerima kuasa. ${ }^{14}$ Dalam hal ini penerima kuasa berkewajiban melaksanakan kuasanya, dan ia menanggung segala biaya, kerugian, dan bunga yang akan timbul karena tidak dilaksananannya kuasa tersebut. ${ }^{15}$ Sedangkan konstruksi hubungan hukum antara pemberi pinjaman dan penerima

14 Antoni Tjandra, 2020, "Kekosongan Norma Penentuan Bunga Pinjaman Financial Technology Peer to Peer Lending", Jurnal Hukum Bisnis Bonum Commune, Vol. 2 No. 1, Fakultas Hukum Universitas 17 Agustus 1945 Surabaya, Surabaya, hlm. 96.

15 Subekti, 2014, Aneka Perjanjian, PT Citra Aditya Bakti, Bandung, hlm. 146. pinjaman adalah hubungan hukum yang lahir dari perjanjian pinjam meminjam sebagaimana diatur dalam Buku III Bab XIII Pasal 1754 s.d Pasal 1773 KUHPerdata, dimana kewajiban penerima pinjaman adalah mengembalikan pinjamannya dan membayar bunga jika diperjanjikan. ${ }^{16}$ Jadi pemberian pinjaman bukan antara penyelenggara dan penerima pinjaman, tetapi antara pemberi pinjaman dan penerima pinjaman. Konstruksi hukum inilah yang membedakan peer to peer lending dengan pemberian kredit, karena pemberian kredit dilakukan secara langsung oleh bank sebagai kreditur kepada nasabah debitur. ${ }^{17}$

Perjanjian yang dilakukan dalam pelaksanaan peer to peer lending tersebut dapat dibagi menjadi dua, yaitu perjanjian antara pemberi pinjaman dengan penyelenggara, dan perjanjian antara pemberi pinjaman dengan penerima pinjaman. Kedua

16 Sentosa Sembiring, 2012, Hukum Perbankan, Mandar Maju, Bandung, hlm. 67.

17 Ratna Hartanto dan Juliyani Purnama Ramli, 2018, "Hubungan Hukum Para Pihak Dalam Peer to Peer to Lending", Jurnal Hukum lus Quia lustum, Vol. 2 No.2, Faculty of Law Universitas Islam Indonesia, hlm. 333-334. 
Indah Kusuma Wardhani dan Fawzia Apriandini

Jurnal Hukum Mimbar Justitia

Vol. 6 No. 2 - Desember 2020

perjanjian tersebut dituangkan dalam dokumen elektronik. Dokumen elektronik yang berisi perjanjian antara penyelenggara dengan pemberi pinjaman paling sedikit harus memuat beberapa hal, yaitu nomor perjanjian; tanggal perjanjian; identitas para pihak; ketentuan mengenai hak dan kewajiban para pihak; jumlah pinjaman; suku bunga pinjaman; besarnya komisi; jangka waktu; rincian biaya terkait; ketentuan mengenai denda (jika ada); mekanisme penyelesaian sengketa; dan mekanisme penyelesaian dalam hal penyelenggara tidak dapat melanjutkan kegiatan operasionalnya. ${ }^{18}$ Sedangkan dokumen elektronik yang berisi perjanjian antara pemberi pinjaman dengan penerima pinjaman paling sedikit harus memuat beberapa hal, yaitu nomor perjanjian; tanggal perjanjian; identitas para pihak; ketentuan mengenai hak dan kewajiban para pihak; jumlah pinjaman; suku bunga pinjaman; nilai angsuran; jangka waktu; objek jaminan (jika ada); rincian biaya terkait; ketentuan mengenai

18 POJK No. 77/POJK.01/2016, Pasal 19 ayat (2). denda (jika ada); dan mekanisme penyelesaian sengketa. ${ }^{19}$

Penandatanganan

kedua perjanjian tersebut dilakukan secara elektronik atau disebut tanda tangan elektronik, yaitu tanda tangan yang terdiri atas informasi elektronik yang dilekatkan, terasosiasi atau terkait dengan informasi elektronik lainnya yang digunakan sebagai alat verifikasi dan autentikasi sebagaimana dimaksud dalam Undang-Undang No. 11 Tahun 2008 tentang Informasi dan Transaksi Elektronik. $^{20}$

Setelah semua petunjuk dan form pada aplikasi sudah diisi hingga terjadi accept/allow, maka berarti calon pengguna telah sepakat untuk menyetujui dan menyatakan kebenaran seluruh data yang diisi dan tunduk pada semua aturan yang ada dalam platform fintech tersebut. Dengan demikian platform akan mengeluarkan sertifikat elektronik yang memuat tanda tangan elektronik dan identitas yang menunjukkan status subjek hukum para pihak dalam transaksi elektronik yang 
Indah Kusuma Wardhani dan Fawzia Apriandini

Jurnal Hukum Mimbar Justitia

Vol. 6 No. 2 - Desember 2020

\begin{tabular}{llllll}
\hline dikeluarkan & oleh & penyelenggara & penyelenggara & termasuk klausul \\
sertifikasi & elektronik & sebagaimana & disclaimer. & \\
& & &
\end{tabular}

11 Tahun 2008 tentang Informasi dan

Transaksi Elektronik. ${ }^{21}$

Berikut ini diuraikan pelaksanaan peer to peer lending secara lebih lengkap sebagai berikut: Dalam hal calon pengguna akan menjadi pihak pemberi pinjaman, maka ia harus terlebih dahulu mendaftarkan dirinya sebagai pemberi pinjaman dengan cara menyerahkan dokumen dan data elektronik yang terkait dengan datadata pribadinya antara lain: nama lengkap, alamat e-mail, nomor handphone, nomor KTP, nomor NPWP (jika memiliki NPWP), nomor rekening bank yang akan digunakan, dan jumlah uang yang akan diinvestasikan atau dipinjamkan. Setelah semua data tersebut diverifikasi oleh penyelenggara, maka akan ada petunjuk persetujuan yang harus disetujui oleh pemberi pinjaman yang mana salah satu dari persetujuan tersebut adalah mematuhi setiap aturan-aturan yang ditetapkan oleh

Selain itu, pemberi pinjaman harus mematuhi setiap isi perjanjian yang dilakukan antara pemberi pinjaman dengan pihak penyelenggara dan perjanjian antara pemberi pinjaman dengan pihak penerima pinjaman. Pemberi pinjaman yang telah diverifikasi akan mendapatkan datadata dari beberapa penerima pinjaman yang sudah terdaftar dan terverifikasi oleh penyelenggara. Selanjutnya, pemberi pinjaman dapat memilih salah satu dari beberapa penerima pinjaman tersebut. Jika sudah terjadi kesepakatan antara pemberi pinjaman dan penerima pinjaman, maka pemberi pinjaman akan mendapatkan return dari hasil bunga pembayaran angsuran pinjaman tersebut.

Berikut ini diuraikan salah satu contoh klausul disclaimer yang harus disetujui oleh pemberi pinjaman:

“Layanan Pinjam Meminjam
Berbasis Teknologi Informasi
merupakan kesepakatan perdata
antara Pemberi Pinjaman dengan
Penerima Pinjaman, sehingga


Indah Kusuma Wardhani dan Fawzia Apriandini

Jurnal Hukum Mimbar Justitia

Vol. 6 No. 2 - Desember 2020

segala risiko yang timbul dari kesepakatan tersebut ditanggung sepenuhnya oleh masing-masing pihak.

Risiko kredit atau gagal bayar ditanggung sepenuhnya oleh Pemberi Pinjaman. Tidak ada lembaga atau otoritas negara yang bertanggung jawab atas risiko gagal bayar ini. Penyelenggara dengan persetujuan dari masing-masing Pengguna (Pemberi Pinjaman dan/atau Penerima Pinjaman) mengakses, memperoleh, menyimpan, mengelola dan/atau menggunakan data pribadi Pengguna ("Pemanfaatan Data") pada atau di dalam benda, perangkat elektronik (termasuk smartphone atau telepon seluler), perangkat keras (hardware) maupun lunak (software), dokumen elektronik, aplikasi atau sistem elektronik milik Pengguna atau yang dikuasai Pengguna, dengan memberitahukan tujuan, batasan dan mekanisme Pemanfaatan Data tersebut kepada Pengguna yang bersangkutan sebelum memperoleh persetujuan yang dimaksud.

Pemberi Pinjaman yang belum memiliki pengetahuan dan pengalaman pinjam meminjam, disarankan untuk tidak menggunakan layanan ini. Penerima Pinjaman harus mempertimbangkan tingkat bunga pinjaman dan biaya lainnya sesuai dengan kemampuan dalam melunasi pinjaman. Setiap kecurangan tercatat secara digital di dunia maya dan dapat diketahui masyarakat luas di media sosial. Pengguna harus membaca dan memahami informasi ini sebelum membuat keputusan menjadi Pemberi Pinjaman atau Penerima Pinjaman.

Pemerintah dalam hal ini Otoritas Jasa Keuangan, tidak bertanggung jawab atas setiap pelanggaran atau ketidakpatuhan oleh Pengguna, baik Pemberi Pinjaman maupun Penerima Pinjaman (baik karena kesengajaan atau kelalaian Pengguna) terhadap ketentuan peraturan perundangundangan maupun kesepakatan atau perikatan antara Penyelenggara dengan Pemberi Pinjaman dan/atau Penerima Pinjaman.

Setiap transaksi dan kegiatan pinjam meminjam atau pelaksanaan kesepakatan mengenai pinjam meminjam antara atau yang melibatkan 
Indah Kusuma Wardhani dan Fawzia Apriandini

Jurnal Hukum Mimbar Justitia

Vol. 6 No. 2 - Desember 2020

Penyelenggara, Pemberi Pinjaman dan/atau Penerima Pinjaman wajib dilakukan melalui escrow account dan virtual account sebagaimana yang diwajibkan berdasarkan Peraturan Otoritas Jasa Keuangan Nomor 77/POJK.01/2016 tentang Layanan Pinjam Meminjam Uang Berbasis Teknologi Informasi dan pelanggaran atau ketidakpatuhan terhadap ketentuan tersebut merupakan bukti telah terjadinya pelanggaran hukum oleh Penyelenggara sehingga Penyelenggara wajib menanggung ganti rugi yang diderita oleh masing- masing Pengguna sebagai akibat langsung dari pelanggaran hukum tersebut di atas tanpa mengurangi hak Pengguna yang menderita kerugian menurut Kitab Undang-Undang Hukum Perdata."22

Berdasarkan klausul tersebut, jelas bahwa pihak penyelenggara tidak akan mengganti kerugian akibat risiko kredit (gagal bayar). Artinya, risiko kredit harus ditanggung sepenuhnya oleh pemberi pinjaman. Padahal dalam pelaksanaan peer to peer lending,

22 https://www.indodana.id/disclaimer, diakses tanggal 14 Agustus 2020 pukul 13.50 WIB. pemberi pinjaman hanya mendapatkan data-data mengenai penerima pinjaman, sedangkan keseluruhan proses verifikasi dan penilaian terhadap penerima pinjaman dilakukan oleh penyelenggara. Selain itu, hasil verifikasi dan penilaian terhadap penerima pinjaman hanya menyebutkan bahwa penerima pinjaman memiliki risiko gagal bayar rendah, sedang, dan tinggi. Oleh karena itu, pemberi pinjaman harus lebih berhati-hati ketika memilih salah satu dari beberapa penerima pinjaman.

Selanjutnya dalam hal calon pengguna akan menjadi pihak penerima pinjaman, maka ia harus terlebih dahulu mendaftarkan dirinya sebagai penerima pinjaman dengan cara menyerahkan dokumen dan data elektronik yang terkait dengan datadata pribadinya antara lain: nama lengkap, alamat e-mail, nomor handphone, nomor KTP, nomor NPWP (jika memiliki NPWP), nomor rekening bank yang akan digunakan, dan jumlah pinjaman dan jangka waktu angsuran pembayaran pinjaman. 
Setelah semua data tersebut diverifikasi dan dilakukan penilaian oleh penyelenggara, maka calon pengguna telah menjadi penerima pinjaman. Ini berarti bahwa penerima pinjaman harus mematuhi setiap aturan yang telah ditetapkan oleh penyelenggara, termasuk klausul disclaimer. Kemudian setiap data-data penerima pinjaman yang telah diisi melalui form pendaftaran penerima pinjaman, kecuali identitas penerima pinjaman, diberikan kepada pemberi pinjaman, dan pemberi pinjaman akan memilih salah satu dari beberapa penerima pinjaman. Setelah menentukan pilihannya, terjadilah kesepakatan antara pemberi pinjaman dengan penerima pinjaman yang dituangkan dalam dokumen elektronik. Perjanjian ini dibuat melalui sebuah platform (aplikasi) yang dimiliki oleh penyelenggara, sehingga semua klausul yang tercantum dalam perjanjian telah dibuat oleh penyelenggara, termasuk besaran bunga pinjaman. Jika semua proses sudah selesai, maka uang pinjaman akan ditransfer ke penerima pinjaman melalui escrow account dan virtual account sehingga tidak melalui rekening penyelenggara.

Escrow account merupakan rekening giro di bank atas nama penyelenggara yang merupakan titipan dan digunakan untuk tujuan tertentu yaitu penerimaan dan pengeluaran dana dari dan kepada pengguna jasa layanan pinjam meminjam uang berbasis teknologi informasi, sedangkan virtual account merupakan layanan perbankan yang termasuk dalam escrow account yang berupa nomor identifikasi pengguna jasa penyelenggara (end user) dan dapat dibuat oleh penyelenggara atau bank yang bertujuan untuk mengidentifikasi penerimaan dan pengeluaran dana dari dan atau kepada suatu rekening.

Berdasarkan uraian tersebut, pada dasarnya pelaksanaan peer to peer lending tidak jauh berbeda dengan pelaksanaan pemberian kredit, karena keduanya merupakan perjanjian pemberian pinjaman. Jadi yang membedakan hanyalah prosesnya, dimana proses pemberian kredit dilakukan secara langsung dalam arti bank bertemu secara langsung dengan 
Indah Kusuma Wardhani dan Fawzia Apriandini

Jurnal Hukum Mimbar Justitia

Vol. 6 No. 2 - Desember 2020

debitur, sedangkan proses peer to peer

lending dilakukan secara tidak langsung dalam arti pemberi pinjaman bertemu melalui media teknologi informasi (online) dengan penerima pinjaman.

\section{B. Perlindungan Hukum Bagi \\ Pemberi Pinjaman Atas Risiko Kredit Dalam Pelaksanaan}

Pinjam Meminjam Uang Berbasis

Teknologi Informasi (Peer to Peer Lending).

Perlindungan hukum merupakan suatu upaya yang dilakukan oleh negara untuk melindungi setiap warga negaranya dalam melakukan setiap hal dalam memenuhi kebutuhan hidupnya guna tercapainya negara yang adil dan sejahtera. Dalam pelaksanaannya, perlindungan hukum terbagi menjadi dua, yaitu perlindungan hukum preventif dan perlindungan hukum represif. Perlindungan hukum preventif merupakan perlindungan hukum yang dilakukan sebelum terjadinya sengketa atau pelanggaran, atau sering disebut pencegahan, sedangkan perlindungan hukum represif merupakan perlindungan hukum yang dilakukan setelah terjadinya sengketa atau
pelanggaran. ${ }^{23}$
Pada saat ini yang menjadi pertimbangan dalam pelaksanaan konsep perlindungan hukum terhadap konsumen tidak hanya pada sektor produk atau jasa layanan keuangan konvensional, tetapi juga pada produk atau jasa layanan keuangan yang dipasarkan melalui teknologi. Perkembangan teknologi telah mengubah bentuk tatanan industri layanan dan jasa keuangan termasuk dalam mengubah strategi dan metode lembaga keuangan dalam memasarkan produk atau jasa yang dimilikinya. Kemudahan dan kecepatan dari pemanfaatan teknologi inilah yang menjadi daya tarik tersendiri dalam pengembangannya secara maksinal dalam bidang keuangan. Selain itu, dengan pemanfaatan teknologi dalam bidang keuangan maka berdampak kepada makin luasnya jangkauan yang dapat ditembus oleh produk atau jasa layanan keuangan.

23 Salim HS dan Erlis Septiana Nurbani, 2014, Penerapan Teori Hukum Pada Penelitian Tesis Dan Disertasi, PT RajaGrafindo Persada, Jakarta, hlm. 264. 
Hal inilah yang menjadikan fintech dapat berkembang dengan sangat pesat di Indonesia yaitu dengan kemudahan yang ditawarkan serta dapat diakses di setiap wilayah Indonesia menjadikan fintech menjadi jalan baru bagi masyarakat yang membutuhkan pinjaman dengan sederhana, mudah, cepat, serta tanpa harus memiliki agunan. Melihat perkembangan fintech yang begitu cepat, terutama layanan peer to peer lending, membuat OJK sebagai lembaga yang bertugas untuk mengawasi dan bertanggung jawab atas segala kegiatan lembaga keuangan mengeluarkan POJK No. 77/POJK.01/2016, dimana peraturan tersebut dikeluarkan untuk mengatur kegiatan dan pelaksanaan peer to peer lending sehingga diharapkan dapat meminimalisir terjadinya risiko yang dapat mengakibatkan kerugian bagi pihak pengguna sebagai konsumen.

Salah satu risiko yang sering terjadi pada pelaksanaan peer to peer lending adalah risiko kredit, yaitu risiko akibat kegagalan penerima pinjaman untuk memenuhi kewajibannya kepada pemberi pinjaman. Melalui platform yang disediakan oleh pihak penyelenggara, siapa saja dapat dengan mudah menjadi pemberi pinjaman karena syarat dan ketentuan bagi calon pengguna layanan peer to peer lending sangat mudah dan tidak terlalu kompleks sebagaimana pada bank dan perusahaan pemberi pinjaman lainnya. Hal ini dapat menyebabkan kesalahan penilaian risiko pada penerima pinjaman, kondisi gagal bayar, dan akhirnya menyebabkan kerugian bagi pemberi pinjaman. Untuk meminimalisir terjadinya risiko kredit tersebut, diperlukan adanya perlindungan hukum bagi pemberi pinjaman, baik perlindungan hukum yang bersifat preventif maupun represif. Perlindungan hukum preventif secara umum diatur dalam POJK No. 77/POJK.01/2016 diantaranya di dalam: 1) Pasal 6 POJK No. 77/POJK.01/2016. Menurut pasal tersebut, batas maksimum total pemberian pinjaman dana kepada setiap penerima pinjaman ditetapkan sebesar Rp 2.000.000.000,00 (dua miliar 


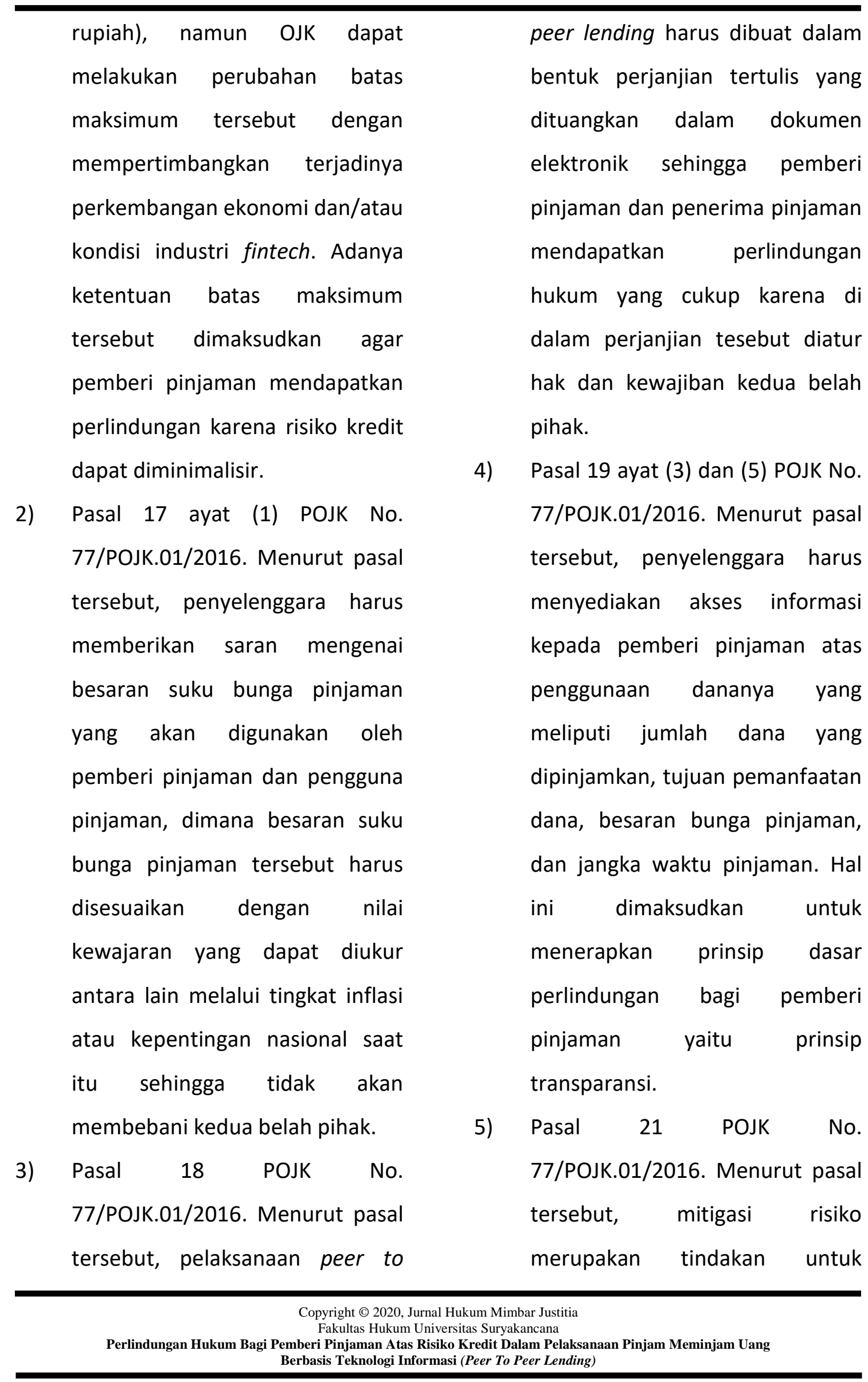




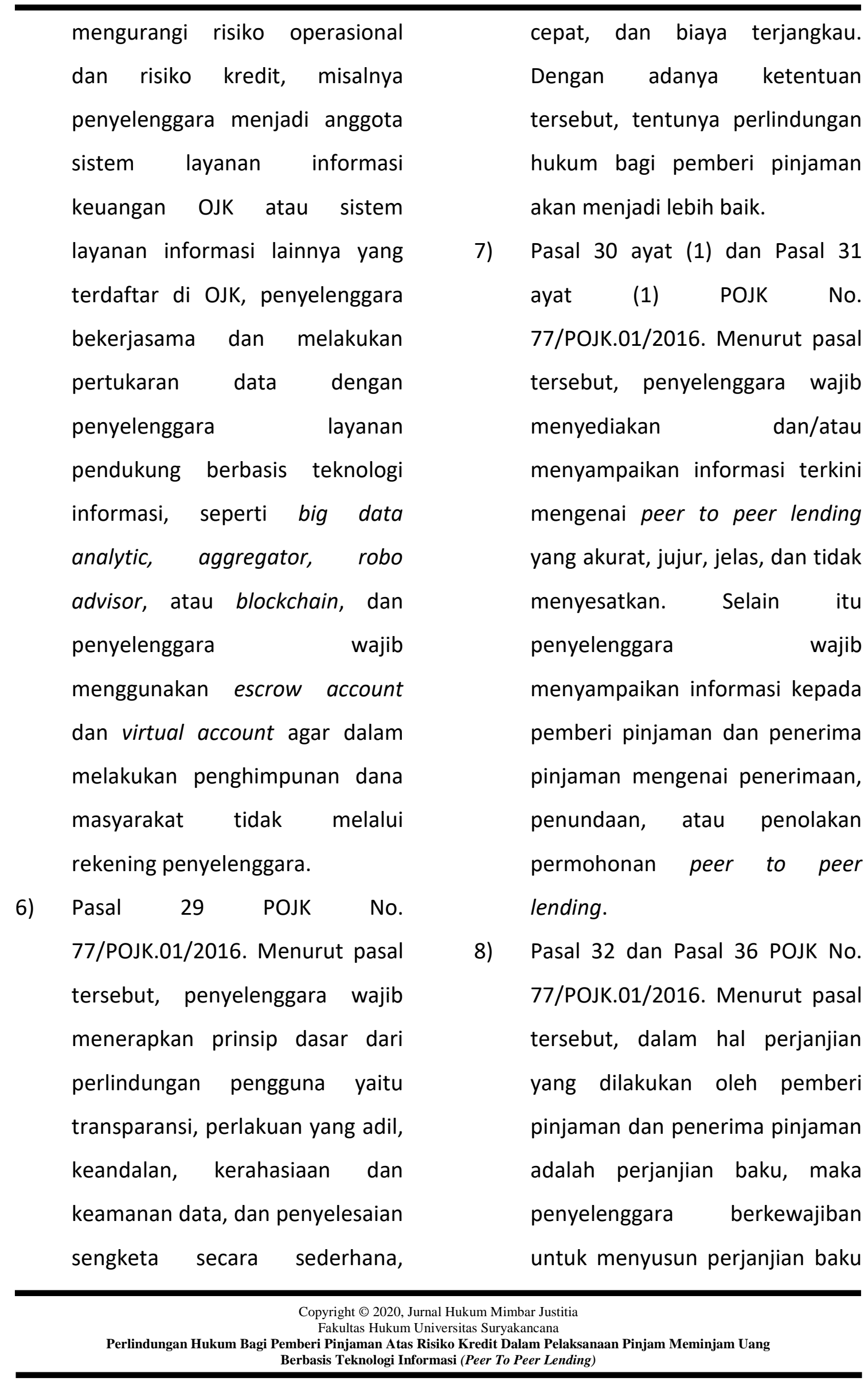


Indah Kusuma Wardhani dan Fawzia Apriandini

Jurnal Hukum Mimbar Justitia

Vol. 6 No. 2 - Desember 2020

tersebut sesuai dengan peraturan

perundang-undangan yang

berlaku di Indonesia serta

menggunakan istilah, frasa,

dan/atau kalimat yang sederhana

dalam bahasa Indonesia agar

mudah dibaca dan dimengerti

oleh pemberi pinjaman dan

penerima pinjaman.

9) Pasal 34 POJK No.

77/POJK.01/2016. Ketentuan ini

dimaksudkan agar pengguna

tidak hanya tergiur pada mudah

dan cepatnya proses peer to peer

lending, akan tetapi juga harus

memikirkan seberapa besar

kemampuannya dalam

melaksanakan kewajibannya. Jadi

bagi penerima pinjaman, ia harus

berhati-hati dalam menerima

pinjaman karena jumlah pinjaman

dan besaran suku bunga

pinjaman harus disesuaikan

dengan kemampuannya dalam

mengembalikan pinjamannya.

Sebaliknya bagi pemberi

pinjaman, ia harus berhati-hati

dalam melakukan investasi di

peer to peer lending karena tidak ada agunan jika terjadi kredit macet.

10) Pasal 37 POJK No. 77/POJK.01/2016. Dengan adanya ketentuan ini, pemberi pinjaman akan mendapatkan perlindungan hukum karena penyelenggara harus bertanggung jawab jika risiko kredit disebabkan oleh kesalahan dan/atau kelalaian pengurus, pegawai penyelenggara dan/atau pihak ketiga yang bekerja untuk kepentingan penyelenggara.

Selanjutnya terkait perlindungan hukum represif, POJK No. 77/POJK.01/2016 juga mengatur perlindungan hukum bagi pemberi pinjaman setelah terjadinya sengketa atau pelanggaran, yaitu:

1) Pasal 27 POJK No. 77/POJK.01/2016 yang mengatur mengenai kewajiban penyelenggara untuk menyediakan rekam jejak audit terhadap seluruh kegiatannya di dalam sistem elektronik layanan peer to peer lending sehingga dapat digunakan untuk keperluan 
Indah Kusuma Wardhani dan Fawzia Apriandini

Jurnal Hukum Mimbar Justitia

Vol. 6 No. 2 - Desember 2020

\section{pengawasan, penegakan hukum, penyelesaian sengketa, verifikasi, pengujian, dan pemeriksaan lainnya. \\ 2) Pasal 38 POJK No. 77/POJK.01/2016 yang mengatur mengenai kewajiban penyelenggara untuk memiliki standar prosedur operasional terkait penyampaian dan penyelesaian pengaduan dalam melayani pengguna yang dimuat dalam dokumen elektronik.}

3) Pasal 40 POJK No. 77/POJK.01/2016 yang mengatur mengenai kewajiban penyelenggara untuk melaporkan secara elektronik setiap bulan jika terdapat pengaduan pengguna disertai dengan tindak lanjut penyelesaian pengaduan tersebut kepada OJK.

Selain itu, OJK telah mengeluarkan peraturan mengenai perlindungan konsumen di sektor jasa keuangan, yaitu POJK No. 1/POJK.07/2013 tentang Perlindungan Konsumen Sektor Jasa Keuangan. Dalam POJK tersebut, diatur perlindungan hukum represif bagi pemberi pinjaman, yaitu Pasal 40 sampai dengan Pasal 46 pada Bab III tentang Pengaduan Konsumen dan Pemberian Fasilitas Penyelesaian Oleh OJK.

Berdasarkan ketentuan tersebut, dapat dilihat bahwa pemberian layanan pengaduan tidak hanya menjadi kewajiban bagi penyelenggara tetapi juga menjadi kewajiban bagi OJK selaku otoritas yang bertugas untuk menjaga keamanan dan ketertiban pada setiap pelaksanaan peer to peer lending. Dalam hal ini OJK mempunyai fungsi untuk saling mempertemukan para pihak, khususnya penyelenggara dan pengguna yang masalahnya tidak bisa diatasi hanya oleh kedua belah pihak tersebut, sehingga diperlukan bantuan dari OJK sebagai fasilitator untuk mengkaji secara lebih dalam permasalahan tersebut agar dapat terselesaikan dengan baik.

Terkait dengan perlindungan hukum bagi pemberi pinjaman atas risiko kredit dalam peer to peer lending, pada dasarnya POJK No. 77/POJK.01/2016 dan POJK No. 
Indah Kusuma Wardhani dan Fawzia Apriandini

Jurnal Hukum Mimbar Justitia

Vol. 6 No. 2 - Desember 2020

1/POJK.07/2013 telah memberikan perlindungan hukum yang cukup, namun perlindungan tersebut harus lebih ditingkatkan, terutama dalam hal mitigasi risiko kredit. Salah satu upaya yang dapat dilakukan oleh penyelenggara untuk mengurangi risiko kredit adalah melakukan penilaian/analisis terhadap calon penerima pinjaman dan memberikan informasi secara detail mengenai calon penerima pinjaman tersebut kepada pemberi pinjaman. Sebenarnya upaya ini sudah mulai dilakukan, tetapi masih dalam tahap pembahasan antara OJK dengan Asosiasi Fintech Pendanaan Bersama Indonesia (AFPI). Nantinya setelah pembahasan, akan dirilis sebuah Pusat Data Fintech Lending (PUSDAFIL) yang memiliki cara kerja yang hampir sama dengan Sistem Informasi Layanan Keuangan (SILK). PUSDAFIL akan digunakan sebagai pusat data bagi calon penerima pinjaman yang akan langsung dipantau oleh OJK dan AFPI, serta akan melakukan kerja sama dengan seluruh perusahaan fintech peer to peer lending yang telah memiliki izin dari OJK. ${ }^{24}$ Dengan adanya PUSDAFIL diharapkan akan mengurangi segala risiko yang ada dalam pelaksanaan peer to peer lending, terutama risiko kredit, karena seluruh data yang terdapat di dalam PUSDAFIL merupakan data-data akurat mengenai para calon penerima pinjaman yang telah terverifikasi dan dianalisis oleh OJK dan AFPI sehingga mempunyai tingkat keakuratan yang tinggi.

Selain itu, upaya untuk mengurangi risiko kredit juga dapat dilakukan dengan cara mengalihkan risiko kredit tersebut kepada perusahaan asuransi melalui asuransi kredit, sehingga ketika terjadi gagal bayar karena penerima pinjaman meninggal atau terkena Pemutusan Hubungan Kerja (PHK) maka perusahaan asuransi dapat melunasi pinjaman tersebut. Dalam asuransi kredit, bentuk pelunasan pinjaman ada tiga, yaitu pembayaran sisa pinjaman

24

https://www.cnbcindonesia.com/tech/2019 0207113947-37-54253/ojk-asosiasi-bentukbi-checking-fintech-buat-apa, diakses tanggal 14 Agustus 2020 pukul 19.10 WIB. 


\begin{abstract}
tanpa tunggakan dan bunga, pembayaran sisa pinjaman ditambah tunggakan dan bunga maksimal 3 bulan, dan pembayaran sebesar pinjaman awal (full limit). ${ }^{25}$ Untuk mewujudkan asuransi kredit, seharusnya OJK sebagai lembaga yang berfungsi menyelenggarakan sistem pengaturan dan pengawasan terhadap seluruh kegiatan di dalam sektor jasa keuangan untuk membuat aturan yang mewajibkan penyelenggara bekerja sama dengan perusahaan asuransi agar perlindungan hukum bagi pemberi pinjaman atas risiko kredit dalam peer to peer lending menjadi lebih baik lagi.
\end{abstract}

\section{PENUTUP}

\section{A. Kesimpulan.}

1. Pelaksanaan peer to peer lending di Indonesia sebagaimana diatur dalam POJK No. 77/POJK.01/2016 melibatkan tiga pihak, yaitu penyelenggara, penerima pinjaman, dan pemberi pinjaman. Perjanjian yang dibuat di antara

25 https://sikapiuangmu.ojk.go.id/FrontEnd/C MS/Category/134, diakses tanggal 15 Agustus 2020 pukul 17.15 WIB. para pihak meliputi perjanjian antara penyelenggara dengan pemberi pinjaman dan perjanjian antara pemberi pinjaman dengan penerima pinjaman. Jadi dalam hal ini, penyelenggara menyediakan sebuah platform (aplikasi) yang mempertemukan calon pengguna, yaitu calon pemberi pinjaman dan calon penerima pinjaman, serta memberikan penilaian dan verifikasi data terhadap seluruh calon pengguna. Setelah dilakukan penilaian dan verifikasi, pengguna dan penyelenggara menyepakati perjanjian yang dituangkan dalam dokumen elektronik serta mematuhi setiap aturan yang telah ditetapkan oleh penyelenggara, termasuk klausul disclaimer. Selanjunya uang pinjaman akan ditransfer ke penerima pinjaman melalui escrow account dan virtual account agar tidak melalui rekening penyelenggara.

2. Bentuk perlindungan hukum bagi pemberi pinjaman atas risiko 
kredit dalam pelaksanaan peer to peer lending ada dua, yaitu perlindungan hukum yang bersifat preventif dan represif. Perlindungan hukum preventif merupakan perlindungan hukum yang dilakukan sebelum terjadinya sengketa/pelanggaran dan diatur dalam POJK No. 77/POJK.01/2016, khususmya Pasal 6, Pasal 17 ayat (1), Pasal 18, Pasal 19 ayat (3) dan (5), Pasal 21, Pasal 29, Pasal 30 ayat (1), Pasal 31 ayat (1), Pasal 32, Pasal 34, Pasal 36, dan Pasal 37. Sedangkan perlindungan hukum represif merupakan perlindungan hukum yang dilakukan setelah terjadinya sengketa/pelanggaran dan diatur dalam POJK No. 77/POJK.01/2016, khususnya Pasal 27, Pasal 38, dan Pasal 40, serta POJK No. 1/POJK.07/2013, khususnya Pasal 40 sampai dengan Pasal 46. Dengan demikian kedua Peraturan OJK tersebut telah memberikan perlindungan hukum yang cukup bagi pemberi pinjaman, namun perlindungan tersebut harus lebih ditingkatkan, terutama dalam hal mitigasi risiko kredit.

\section{B. Saran}

1. Diharapkan OJK dan AFPI segera merilis Pusat Data Fintech Lending (PUSDAFIL) agar dapat digunakan oleh seluruh perusahaan fintech dengan sistem peer to peer lending dalam melakukan penilaian/analisis dan verifikasi data dari setiap calon penerima pinjaman sehingga pemberi pinjaman bisa mendapatkan data-data tersebut sebelum ia memberikan pinjamannya kepada penerima pinjaman.

2. Diharapkan OJK sebagai lembaga yang berfungsi menyelenggarakan sistem pengaturan dan pengawasan terhadap seluruh kegiatan di dalam sektor jasa keuangan dapat membuat aturan yang mewajibkan perusahaan fintech dengan sistem peer to peer lending bekerja sama dengan perusahaan asuransi untuk 
Indah Kusuma Wardhani dan Fawzia Apriandini

Jurnal Hukum Mimbar Justitia

Vol. 6 No. 2 - Desember 2020

mengurangi risiko kredit agar

perlindungan hukum bagi

\section{DAFTAR PUSTAKA}

A. Buku.

Elsi Kartika Sari dan Advendi Simangunsong, 2007, Hukum Dalam Ekonomi, PT Gramedia Widiasarana, Jakarta.

Gazali S. Djoni dan Rachmadi Usman, 2010, Hukum Perbankan, Sinar Grafika, Jakarta.

Nurudin, 2012, Media Sosial Baru dan Munculnya Revolusi Proses Komunikasi, Buku Litera, Yogyakarta.

Otoritas Jasa Keuangan, 2017, Kajian Perlindungan Konsumen Sektor Jasa Keuangan: Perlindungan Konsumen Pada Fintech, Departemen Perlindungan Konsumen OJK, Jakarta.

Salim HS dan Erlis Septiana Nurbani, 2014, Penerapan Teori Hukum Pada Penelitian Tesis Dan Disertasi, PT RajaGrafindo Persada, Jakarta.

Sentosa Sembiring, 2012, Hukum Perbankan, Mandar Maju, Bandung.

Soerjono Soekanto, 2012, Pengantar Penelitian Hukum, UI Press, Jakarta. pemberi pinjaman menjadi lebih baik lagi.

Subekti, 2014, Aneka Perjanjian, PT Citra Aditya Bakti, Bandung.

B. Peraturan Perundang-Undangan. Undang-Undang Dasar Negara Republik Indonesia Tahun 1945.

Undang-Undang No. 11 Tahun 2008 Tentang Informasi dan Transaksi Elektronik.

Peraturan Otoritas Jasa Keuangan No. 1/POJK.07/2013 tentang Perlindungan Konsumen Sektor Jasa Keuangan.

Peraturan Otoritas Jasa Keuangan No. 77/POJK.01/2016 tentang Layanan Pinjam Meminjam Uang Berbasis Teknologi Informasi.

C. Jurnal.

Antoni Tjandra, 2020, Kekosongan Norma Penentuan Bunga Pinjaman Financial Technology Peer to Peer Lending, Jurnal Hukum Bisnis Bonum Commune, Vol. 2 Issue 1, Fakultas Hukum Universitas 17 Agustus 1945 Surabaya, Surabaya.

Dita Tania Pratiwi, 2020, Perlindungan Hukum Terhadap Konsumen (Penerima Pinajaman) Financial Technology yang Berbasis Peer to Peer Lending di Indonesia, Jurnal Hukum Adiguna, Vol. 3 Issue 1, Fakultas Hukum Universitas Tarumanegara, Jakarta. 
Indah Kusuma Wardhani dan Fawzia Apriandini Jurnal Hukum Mimbar Justitia

Vol. 6 No. 2 - Desember 2020

Ratna Hartanto dan Juliani Purnama Ramli, 2018, Hubungan Hukum Para Pihak Dalam Peer to Peer Lending, Jurnal Hukum IUS Quia lustum, Vol. 25 Issue 2, Fakultas Hukum UII, Yogyakarta.

D. Internet.

https://finance.detik.com/moneter/d4522143/ojk-sebut-cuma-60orang-ri-punya-rekening-bank. Diakses tanggal 10 Agustus 2020.

https://kbbi.kemdikbud.go.id/entri/per intis. Diakses tanggal 10 Agustus 2020.

https://www.ojk.go.id/id/berita-dankegiatan/publikasi/Pages/Penyele nggara-Fintech-Terdaftar-danBerizin-di-OJK-per-31-Mei-2019.

Diakses tanggal 12 Agustus 2020.

https://www.cnbcindonesia.com/fintec h/20190401112121-37- 64008/kredit-macet-fintechtembus-318-perlukah-khawatir. Diakses 12 Agustus 2020.

https://www.cnbcindonesia.com/tech/ 20191014113024-37-

106736/berkat-fintech-lendingsederet-umkm-ini-bisa-naik-kelas. Diakses 12 Agustus 2020.

https://www.indodana.id/disclaimer. Diakses 14 Agustus 2020.

https://www.cnbcindonesia.com/tech/ 20190207113947-37-54253/ojkasosiasi-bentuk-bi-checkingfintech-buat-apa. Diakses 14 Agustus 2020.

https://sikapiuangmu.ojk.go.id/FrontEn d/CMS/Category/134. Diakses 15 Agustus 2020. 